\title{
HUBUNGAN PERAN SUAMI TERHADAP PEMILIHAN JENIS ALAT KONTRASEPSI KB PADA IBU DI KELURAHAN KEBONSARI KABUPATEN JEMBER
}

\author{
(The Correlation Between Role of Husband toward Wife Choice of Contraception device KB \\ (Family Planning) on \\ Kebonsari Village At Jember Regency) \\ Julvainda Eka Priya Utama, Ratna Sari H, Erti Ikhtiarini D \\ e-mail korespondensi: julvaindaeka@gmail.com
}

\begin{abstract}
The role of husband in family is very important, especially to support and making a decision in KB (Family Planning) program. This research intends to figure out the correlation role of husband toward wife choice of contraception. This research used Observational analytic design with cross sectional approach. samples collected used multistage random sampling technique and total sample are 94 respondents. Data was analyzed by chi-square. The result of the research showed 54,3\% husbands has did his role. The majority respondents used a type of hormonal contraception. The results of statistical tests $p$-value (0.016) $<\alpha(0.05)$, it mean there is a correlation between the husband's role in his wife choice of KB (Family Planning) contraception. The result of $O R(0,241)$, husband who did his role, have 0,241 of possibility or tendency to choose hormonal KB device of contraception. Health workers are expected to improve program family planning counseling and to motivate the husband in monitoring his wife while using the contraceptions. It expected to BKKBN with community health center become corporate to promote counseling services and information about contraception can be conducted periodically.
\end{abstract}

Keywords: Role Husband, Wife Choice of Contraception Device KB (Family Planning) 


\begin{abstract}
ABSTRAK
Peran suami dalam keluarga sangatlah penting terutama dalam mendukung dan mengambil keputusan dalam program KB. Penelitian ini bertujuan untuk mengetahui hubungan peran suami terhadap pemilihan jenis alat kontrasepsi KB pada ibu. Penelitian ini menggunakan observational analitik dengan pendekatan crossectional. Pengambilan sampel menggunakan teknik multistage random sampling dengan jumlah sampel 94 responden. Data dianalisis menggunakan chi-square. Hasil penelitian menunjukkan peran suami dilakukan $54.3 \%$. Mayoritas responden menggunakan jenis kontrasepsi hormonal. Hasil uji statistic nilai p (0.016) $<\alpha(0,05)$ disimpulkan terdapat hubungan antara peran suami terhadap pemilihan jenis kontrasepsi KB pada ibu. OR $(0,241)$, berarti peran suami yang dilakukan memiliki kemungkinan terhadap pemilihan jenis alat kontrasepsi KB hormonal pada ibu sebesar 0,241. Diharapkan petugas kesehatan meningkatkan program konseling KB dan memotivasi suami dalam melakukan pengawasan alat kontrasepsi yang digunakan istri. BKKBN diharapkan bekerjasama dengan puskesmas untuk mengedepankan pelayanan informasi maupun konseling tentang kontrasepsi yang dapat dilakukan secara periodik.
\end{abstract}

Kata kunci: Peran Suami, Pemilihan Jenis Alat Kontrasepsi KB pada Ibu

\section{PENDAHULUAN}

Program Keluarga Berencana merupakan bagian terpadu dalam program pembangunan nasional yang bertujuan untuk mewujudkan penduduk Indonesia tumbuh seimbang agar kesejahteraan ekonomi, spiritual, dan sosial budaya dapat tercapai [1].

Kabupaten Jember merupakan kabupaten dengan jumlah PUS terbanyak di Jawa Timur, dengan presentase KB aktif sebesar 69,64\%. Presentase tersebut masih di bawah cakupan target SPM kabupaten dengan presentase target $70 \%$ (SPM Jember, 2012). Pada Tahun 2014 presentase $\mathrm{KB}$ aktif tersebut terbagi dalam beberapa jenis kontrasepsi antara lain IUD 88.317 (24,18\%), MOW 9.745 (2,67\%), MOP 994 $(0,27 \%)$, Implant $29.581(8,10 \%)$, Suntik $123.292(33,76 \%)$ dan Pil 114.255 $(31,29 \%)[2]$.

Wanita harus menentukan jenis metode kontrasepsi dengan tepat sesuai kondisi dan kebutuhan. Wanita/ibu harus memperhatikan beberapa faktor dalam memilih suatu metode kontrasepsi, wanita/ibu harus memperhatikan berbagai faktor, seperti status kesehatan, efek samping potensial metode kontrasepsi, konsekuensi terhadap kehamilan yang tidak diinginkan, banyaknya anak dalam keluarga yang diinginkan, kerjasama pasangan, dan norma budaya serta agama mengenai kemampuan mempunyai anak [3].

Pemilihan jenis alat kontrasepsi diperlukan pemikiran yang matang antara suami maupun istri karena mereka yang menanggung konsekuensi maupun efek samping dalam melakukan KB. Peran suami dalam KB bisa diwujudkan secara langsung maupun tidak langsung. Partisipasi secara langsung dapat diwujudkan dengan menjadi akseptor KB dan partisipasi suami secara tidak langsung adalah mendukung istri dalam ber-KB yaitu, sebagai motivator dan pengambil keputusan bersama, guna merencanakan jumlah anak dalam keluarga. Peran suami sebagai motivator dengan memberikan motivasi/dorongan untuk menjadi peserta $\mathrm{KB}$ dengan menggunakan salah satu jenis alat kontrasepsi [4].

Kecamatan Sumbersari merupakan kecamatan dengan jumlah PUS terbanyak ke 2 setelah Kecamatan Puger, dengan jumlah PUS sebanyak 26232, sedangkan untuk peserta KB aktif sebanyak 18.268 dengan presentase 69,64 \%. Kecamatan Sumbersari menduduki peringkat pertama kabupaten dengan peserta KB dengan jalur swasta terbanyak sebesar 9983 peserta KB aktif. Kelurahan Kebonsari merupakan salah satu kelurahan yang ada di Kecamatan Sumbersari dengan jumlah akseptor KB tertinggi dengan jumlah 4396 akseptor KB 
dengan jumlah PUS sebesar 6278 [2]. Dari hasil studi pendahuluan di Kelurahan Kebonsari pada bulan Mei 2014, terdapat 8 dari 10 ibu mengatakan bahwa suami tidak tahu tentang waktu kontrol alat kontrasepsi dan cenderung fokus pada pekerjaan.

Peran suami dalam keluarga sangatlah penting terutama dalam mendukung dan mengambil keputusan dalam program KB. Suami mempunyai anggapan bahwa penggunaan alat kontrasepsi $\mathrm{KB}$ itu hanya untuk urusan perempuan, sehingga suami cenderung bersifat pasif apabila menyangkut masalah alat kontrasepsi, oleh karena itu peneliti tertarik untuk meneliti tentang Hubungan peran suami terhadap pemilihan jenis alat kontrasepsi KB pada ibu di Kelurahan Kebonsari Kabupaten Jember.

\section{METODE PENELITIAN}

Penelitian ini merupakan penelitian non eksperimental dengan observasional analitik dengan metode pendekatan cross sectional. Populasi dalam penelitian ini adalah ibu yang menggunakan alat kontrasepsi KB di Kelurahan Kebonsari Kabupaten Jember sebanyak 4396 orang. Teknik pengambilan sampel dilakukan dengan teknik multistage sampling dengan pendekatan random sampling. Jumlah sampel yaitu $94 \mathrm{ibu}$ yang menggunakan kontrasepsi.

Cara pengambilan sampel dengan cara bertahap berdasarkan tingkat wilayah dengan membagi wilayah Kelurahan Kebonsari menjadi 4 Lingkungan yaitu Krajan, Sumber Dandang, Sadengan, Sumber Pakem. Pada 4 Lingkungan tersebut terdapat beberapa RW, Lingkungan Krajan terdapat 8 RW yaitu RW 1 - RW 8, Lingkungan Sumber Dandang terdapat 14 RW yaitu RW 9 - RW 22, Lingkungan Sadengan terdapat 7 RW yaitu RW 23 - RW 29 dan Lingkungan Sumber Pakem terdapat 10 RW yaitu RW 30 - RW 39. Pada tiap RW akan diambil sampel yang akan diteliti dengan proporsi yang sama. Pada Tiap RW akan dipilih secara acak ibu yang menggunakan alat kontrasepsi $\mathrm{KB}$ di RW tersebut.
Waktu penelitian dimulai pada bulan April -Mei 2014. Alat pengumpul data pada penelitian ini adalah lembar kuesioner. Data Peran suami terhadap pemilihan jenis alat kontrasepsi $\mathrm{KB}$ pada ibu diperoleh dari kuesioner yang dibagikan pada responden. Pengolahan data menggunakan uji chisquare dengan derajat kepercayaan 95\% $(\alpha=0,05)$. Peneliti menggunakan tabel silang untuk mengetahui nilai OR. Peneliti menggunakan program SPSS untuk proses pengolahan data dan analisa statistik.

\section{Hasil Penelitian}

Karakteristik Ibu

Tabel 1. Distribusi umur ibu

\begin{tabular}{cccl}
\hline Variabel & Mean & $\begin{array}{l}\text { Modu } \\
\text { s }\end{array}$ & $\begin{array}{l}\text { Min- } \\
\text { Maks }\end{array}$ \\
\hline Umur & 35 & 36 & $26-45$ \\
\hline \multicolumn{2}{c}{ Tabel } & 1 & menunjukkan bahwa rata -
\end{tabular}

rata umur responden berada pada umur 35 tahun dan umur yang sering muncul berada pada umur 36 tahun. Usia termuda responden pada penelitian ini yaitu pada umur 26 tahun dan usia tertua responden pada umur 45 tahun.

Tabel 2. Distribusi karakteristik ibu

\begin{tabular}{lcc}
\hline Karakteristik & $\begin{array}{c}\text { Frekuens } \\
\text { i }\end{array}$ & Persentase \\
\hline \multicolumn{1}{c}{ Agama } & & \\
\hline Islam & 77 & $81.9 \%$ \\
Kristen & 7 & $7.4 \%$ \\
Katolik & 5 & $5.3 \%$ \\
Hindu & 3 & $3.2 \%$ \\
Budha & 2 & $2.1 \%$ \\
\hline Total & 94 & $100 \%$ \\
\hline \multicolumn{1}{c}{ Suku } & & \\
\hline Jawa & 65 & $69.1 \%$ \\
Madura & 29 & $30.9 \%$ \\
\hline Total & 94 & $100 \%$ \\
\hline \multicolumn{1}{c}{ Pendidikan } & & \\
\multicolumn{1}{c}{$\quad$ bbu } & & \\
\hline SD & 10 & $10.6 \%$ \\
SMP & 17 & $18.1 \%$ \\
SMA & 40 & $42.6 \%$ \\
PT & 27 & $28.7 \%$ \\
\hline Total & 94 & $100 \%$ \\
\hline Pekerjaan Ibu & & \\
\hline PNS & 22 & $23.4 \%$
\end{tabular}




\begin{tabular}{|c|c|c|}
\hline $\begin{array}{l}\text { Ibu rumah } \\
\text { tangga }\end{array}$ & 40 & $42.6 \%$ \\
\hline Pedagang & 29 & $30.9 \%$ \\
\hline Petani & 3 & $3.2 \%$ \\
\hline Total & 94 & $100 \%$ \\
\hline $\begin{array}{c}\text { Pekerjaan } \\
\text { Suami }\end{array}$ & $\begin{array}{c}\text { Frekuens } \\
\text { i }\end{array}$ & Presentase \\
\hline PNS & 37 & $39.4 \%$ \\
\hline Swasta & 16 & $17 \%$ \\
\hline Wiraswasta & 33 & $35.1 \%$ \\
\hline Petani & 8 & $8.5 \%$ \\
\hline
\end{tabular}

\begin{tabular}{lcc}
\hline $\begin{array}{c}\text { Jumlah } \\
\text { anak hidup }\end{array}$ & $\begin{array}{c}\text { Frekuens } \\
\text { i }\end{array}$ & Presentase \\
\hline$\leq 2$ & 63 & $67 \%$ \\
$>2$ & 31 & $33 \%$ \\
\hline Total & 94 & $100 \%$ \\
\hline
\end{tabular}

\begin{tabular}{llc}
\hline $\begin{array}{l}\text { Penghasilan } \\
\text { Keluarga }\end{array}$ & & \\
\hline$<$ UMK & 14 & $14.9 \%$ \\
$\geq$ UMK & 80 & $85.1 \%$ \\
\hline Total & 94 & $100.00 \%$ \\
\hline
\end{tabular}

Tabel 2 menunjukkan distribusi karakteristik agama, mayoritas responden beragama islam $81.9 \%$ dan mayoritas responden bersuku Jawa $69.1 \%$. Tingkat pendidikan responden diketahui bahwa tingkat pendidikan SMA merupakan jenjang pendidikan yang paling banyak yaitu sebanyak $42.6 \%$ dan jenjang pendidikan paling sedikit yaitu SD sebanyak $10.6 \%$. Jenis pekerjaan dengan jumlah tertinggi yaitu sebagai ibu rumah tangga $42.65 \%$ dan jenis pekerjaan dengan jumlah terendah yaitu sebagai petani $3.2 \%$.

Jenis pekerjaan dengan jumlah tertinggi yaitu sebagai PNS $39.45 \%$ dan jenis pekerjaan dengan jumlah terendah yaitu sebagai petani $8.5 \%$. Karakteristik jumlah anak hidup dalam keluarga responden. Mayoritas responden mempunyai jumlah anak $\leq 2$ sebanyak $67 \%$ dan sebagian besar keluarga responden berpenghasilan $\geq$ UMK (Upah Minimum Kabupaten Rp 1.270.000). Karakteristik jenis alat kontrasepsi yang digunakan responden pada menunjukkan bahwa jenis alat kontrasepsi pil $27.7 \%$ merupakan jenis alat kontrasepsi yang paling banyak digunakaan oleh responden dan jenis kontrasepsi MOW/tubektomi $6.4 \%$ merupakan jenis kontrasepsi yang paling sedikit digunakaan oleh responden di Kelurahan Kebonsari Kabupaten Jember.

\section{Peran Suami}

Tabel 3. Distribusi peran suami terhadap pemilihan jenis alat kontrasepsi KB pada ibu

\begin{tabular}{lcc}
\hline $\begin{array}{c}\text { Karakterist } \\
\text { ik }\end{array}$ & Frekuensi & Presentase \\
\hline \multicolumn{1}{c}{ Motivator } & & \\
\hline Dilakukan & 53 & $56.4 \%$ \\
\hline $\begin{array}{l}\text { Tidak } \\
\text { Dilakukan }\end{array}$ & 41 & $43.6 \%$ \\
\hline Total & 94 & $100 \%$ \\
\hline
\end{tabular}

\section{Pengambil}

Keputusan

\begin{tabular}{lll}
\hline Dilakukan & 58 & $61.7 \%$ \\
\hline Tidak & 36 & $38.3 \%$ \\
Dilakukan & &
\end{tabular}

\begin{tabular}{ccc}
\hline Total & 94 & $100 \%$ \\
\hline Peran
\end{tabular}

Peran

suami

(Motivator

dan

Pengambil

Keputusan)

\begin{tabular}{|c|c|c|}
\hline Dilakukan & 51 & $54.3 \%$ \\
\hline $\begin{array}{l}\text { Tidak } \\
\text { Dilakukan }\end{array}$ & 43 & $45.7 \%$ \\
\hline Total & 94 & $100 \%$ \\
\hline
\end{tabular}

indikator Peran suami sebagai motivator. Tabel tersebut menunjukkan 56.4\% menyatakan bahwa peran suami sebagai motivator dilakukan dan 43.6\% menunjukkan bahwa peran suami sebagai motivator tidak dilakukan. Distribusi indikator Peran suami sebagai pengambil keputusan. Pada tabel tersebut menunjukkan bahwa $61.7 \%$ menyatakan bahwa peran suami sebagai pengambil keputusan dilakukan dan 38.3\% menunjukkan bahwa peran suami sebagai pengambil keputusan tidak dilakukan.

Tabel 3 menunjukkan bahwa peran suami dilakukan dalam pemilihan jenis alat 
kontrasepsi pada ibu sejumlah $54.3 \%$ dan $45.7 \%$ menyatakan peran suami tidak dilakukan dalam pemilihan jenis alat kontrasepsi KB pada ibu di Kelurahan Kebonsari Kabupaten Jember.

\section{Kategori Pemilihan Jenis Kontrasepsi KB Pada Ibu}

Tabel 4. Distribusi kategori jenis alat kontrasepsi KB pada Ibu

\begin{tabular}{lcc}
\hline Karakteristik & Frekuensi & Presentase \\
\hline $\begin{array}{c}\text { Jenis } \\
\text { Kontrasepsi }\end{array}$ & & \\
\hline Hormonal & 71 & $75.5 \%$ \\
Non Hormonal & 23 & $24.5 \%$ \\
\hline Total & 94 & $100 \%$ \\
\hline
\end{tabular}

Tabel 4 menunjukkan bahwa lebih dari setengah dari total responden memilih jenis alat kontrasepsi hormonal (Pil, Implant dan Suntik) yaitu sejumlah $75.5 \%$ dan sebanyak $24.5 \%$ menggunakan kontrasepsi non hormonal (IUD/AKDR dan Tubektomi/MOW).

\section{Hubungan Peran Suami Terhadap Pemilihan Jenis Alat Kontrasepsi KB pada Ibu}

Tabel 5. Hubungan Peran Suami Terhadap Pemilihan Jenis Alat Kontrasepsi KB pada Ibu

\begin{tabular}{|c|c|c|c|c|c|c|c|c|}
\hline \multirow[t]{3}{*}{$\begin{array}{l}\text { Peran } \\
\text { suami }\end{array}$} & \multicolumn{4}{|c|}{$\begin{array}{c}\text { Jenis } \\
\text { Kontrasepsi }\end{array}$} & \multirow{2}{*}{\multicolumn{2}{|c|}{ Total }} & \multirow[t]{3}{*}{$O R$} & \multirow{3}{*}{$\begin{array}{c}p \\
\text { Valu } \\
e\end{array}$} \\
\hline & \multicolumn{2}{|c|}{$\begin{array}{c}\text { Hormo } \\
\text { nal }\end{array}$} & \multicolumn{2}{|c|}{$\begin{array}{c}\text { Non } \\
\text { Hormo } \\
\text { nal }\end{array}$} & & & & \\
\hline & $\mathrm{n}$ & $\%$ & $\mathrm{n}$ & $\%$ & $\mathrm{n}$ & $\%$ & & \\
\hline Dilak & 3 & 35. & 1 & 19. & 5 & 54. & & \\
\hline ukan & 3 & $1 \%$ & 8 & $1 \%$ & 1 & $3 \%$ & & \\
\hline Tidak & 3 & 40. & 5 & 5.3 & 4 & 45. & 0.2 & 0.0 \\
\hline $\begin{array}{l}\text { Dilak } \\
\text { ukan }\end{array}$ & 8 & $4 \%$ & & $\%$ & 3 & $7 \%$ & 41 & 16 \\
\hline Jumla & 7 & 75. & 2 & 24. & 9 & 10 & & \\
\hline $\mathrm{h}$ & 1 & $5 \%$ & 3 & $5 \%$ & 4 & $0 \%$ & & \\
\hline
\end{tabular}

Tabel 5 menunjukkan bahwa peran suami yang dilakukan yang memilih kontrasepsi Hormonal sejumlah 35.1\% dan Non Hormonal sejumlah 19.1\%. Pada Peran suami yang tidak dilakukan menunjukkan bahwa sejumlah $40.4 \%$ memilih kontrasepsi Hormonal dan 5.3\% memilih Non Hormonal.

Hasil penelitian dengan uji statistik chi square didapatkan $p$ value sebesar 0,016 . Pengambilan keputusan dilakukan dengan melihat derajat kemaknaan $(\alpha=0,05)$. Nilai $p$ value yang didapat dari hasil uji statistik adalah $\leq 0,05$ maka $\mathrm{H} 0$ ditolak dan hasil uji tabel silang untuk mengetahui odds ratio didapatkan hasil 0.241 .

\section{PEMBAHASAN \\ Peran Suami}

Penelitian ini menunjukkan bahwa lebih dari setengah total ibu menunjukkan peran suami dilakukan dalam pemilihan jenis alat kontrasepsi pada ibu dengan presentase $54.3 \%$ dan $45.7 \%$ peran suami tidak dilakukan. Hal ini menunjukkan bahwa lebih dari setengah dari total ibu di Kelurahan Kebonsari Kabupaten Jember menunjukkan peran suami dilakukan. Peran adalah sesuatu yang harus dilakukan individu dalam situasi tertentu agar dapat memenuhi harapan mereka sendiri atau harapan orang lain [5].

Hasil penelitian menunjukkan bahwa indikator peran suami sebagai motivator yang dilakukan menunjukkan presentase sebesar $56.4 \%$. Hal ini menunjukkan bahwa lebih dari setengah total ibu menyatakan peran suami sebagai motivator dilakukan dan terdapat $43.6 \%$ peran suami sebagai motivator tidak dilakukan. Peneliti berasumsi bahwa peran sebagai motivator tidak dilakukan, dipengaruhi oleh beberapa faktor seperti tingkat kesibukan suami, pengalaman dan jumlah anak. Aspek pekerjaan suami juga mempengaruhi peran, pekerjaan suami yang semakin sibuk akan sedikit banyak mengurangi peran suami sebagai motivator dalam pemilihan jenis alat kontrasepsi [6],

Peran suami yang dilakukan dalam indikator pengambilan keputusan menunjukkan presentase $61.7 \%$ dan $38.3 \%$ peran suami sebagai pengambil keputusan tidak dilakukan. Hal ini menunjukkan bahwa mayoritas ibu menyatakan peran suami dalam pengambilan keputusan 
dilakukan. Peran suami sebagai pengambil keputusan pada kategori dilakukan tersebut antara lain terdapat pada point, memberikan saran dalam memilih jenis kontrasepsi, mendiskusikan tentang siapa yang harus menggunakan kontrasepsi, dan suami mencari informasi tentang kontrasepsi yang digunakan istri, dari beberapa point tersebut menunjukkan jumlah paling tinggi dengan menyatakan pilihan pada kriteria "sering". Kategori peran suami sebagai pengambil keputusan yang tidak dilakukan 38,3\%, terdapat nilai yang rendah pada point seperti suami menanyakan ke petugas kesehatan mengenai penggunaan kontrasepsi secara benar, suami mengeluh tentang alat kontrasepsi yang digunakan istri dari beberapa point tersebut menunjukkan jumlah paling tinggi dengan menyatakan pilihan pada kriteria "kadang - kadang" dan point suami menanyakan ke petugas kesehatan tentang keefektifan kontrasepsi yang ibu gunakan kebanyakan ibu menyatakan pilihan pada kriteria "tidak pernah". Persetujuan suami dalam penggunaan jenis kontrasepsi tertentu pada istri yang merupakan faktor paling penting dalam menentukan apakah istri akan menggunakan kontrasepsi atau tidak, karena dalam hal ini suami dipandang sebagai pelindung, pencari nafkah rumah tangga dan pembuat keputusan [6].

Bentuk peran suami dalam penelitian ini secara garis besar telah dilakukan, tetapi terdapat beberapa point nilai yang rendah seperti menemani istri saat kontrol alat kontrasepsi serta ikut mendengarkan pengarahan dari petugas kesehatan dengan aktif dan terkadang suami kurang mencari informasi tentang jenis alat kontrasepsi yang digunakan oleh istri, karena masih terdapat asumsi bahwa alat kontrasepsi itu hanya urusan perempuan. Peneliti berpendapat bahwa peran suami dipengaruhi adanya beberapa faktor seperti tingkat pendidikan, pengalaman, jumlah anak, pekerjaan, budaya, status perkawinan, dan status sosial ekonomi. Pada wilayah Kelurahan Kebonsari secara garis besar merupakan wilayah perkotaan, sehingga penduduknya mampu mengakses informasi, pengetahuan dan pendidikan yang layak, selain itu dari faktor sosial ekonomi menunjukkan bahwa lebih dari setengah dari total keluarga $85.1 \%$ memiliki penghasilan $\geq \mathrm{UMK}$, sehingga dapat menyisihkan penghasilan guna menggunakan maupun kontrol alat kontrasepsi, dari segi budaya kedua suku yang ada di kelurahan kebonsari sama-sama menganut budaya Patrilineal, yaitu suami mempunyai otoritas dalam mengatur keluarga dengan berbagai pertimbangan yang telah didiskusikan dengan pasangan dengan tujuan kesejahteraan keluarga.

\section{Pemilihan Jenis Alat Kontrasepsi KB pada Ibu}

Hasil penelitian menunjukkan bahwa dari ibu masih menyukai penggunaan alat kontrasepsi Hormonal, hal ini dikarenakan kontrasepsi ini mudah untuk didapat, cara penggunaan relatif mudah dan relatif tanpa operasi, tetapi dalam hal ini ibu juga harus mengetahui efek samping dari kontrasepsi hormonal apabila di gunakan secara terus menerus dan ibu juga harus mengetahui tentang jangka waktu pemakaian kontrasepsi hormonal dan apakah terdapat efek samping dari pemakaian kontrasepsi hormonal. Kontrasepsi Non Hormonal yang memerlukan metode bedah minor dan cara pemasangannya relatif lebih rumit daripada jenis hormonal, hanya keunggulannya jenis Non Hormonal memiliki efektivitas lebih tinggi [7].

Ibu yang menggunakan kontrasepsi Non hormonal secara garis besar sudah memiliki anak lebih dari 2, selain itu usia ibu sudah relatif beresiko apabila mengalami kehamilan. Pada pengguna kontrasepsi IUD, ibu mengatakan bahwa suami sering mengeluh karena kurang nyaman saat berhubungan seks, sehingga suami terkadang mengatakan agar mengganti dengan jenis alat kontrasepsi yang lain. Pada jenis kontrasepsi IUD terdapat adanya ekspulsi / terabanya alat kontrasepsi di liang vagina yang dapat menyebabkan rasa kurang nyaman pada beberapa PUS, khususnya suami [7]. Hasil wawancara saat pengisian kuesioner, terdapat beberapa ibu di Kelurahan Kebonsari Kabupaten Jember masih merasa 
takut dan kurang yakin apabila menggunakan jenis kontrasepsi Non Hormonal, dikarenakan prosesnya yang menggunakan prosedur medis (Implant, IUD, MOW) dan terkesan lebih rumit perawatanya daripada penggunaan kontrasepsi jenis Hormonal meskipun jenis Non Hormonal mempunyai tingkat efektivitas yang lebih tinggi daripada jenis Hormonal [1].

\section{Hubungan Peran Suami Terhadap Pemilihan Jenis Alat Kontrasepsi KB pada Ibu}

Peran suami dalam keluarga sangatlah penting, selain sebagai pemimpin dalam keluarga, suami mempunyai kewajiban memberikan yang terbaik bagi keluarganya. Suami mempunyai tanggung jawab dalam suatu keluarga dan mempunyai peranan yang penting, dimana suami dituntut bukan hanya sebagai pencari nafkah tetapi suami sebagai motivator dan pengambil keputusan dalam berbagai kebijakan yang akan diputuskan termasuk merencanakan keluarga [7]. Keterlibatan Suami dalam KB dan kesehatan reproduksi didasarkan bahwa suami adalah mitra reproduksi dan seksual bagi istri, sehingga sangat beralasan apabila suami mempunyai tanggung jawab dan peran secara seimbang untuk mencapai kepuasan kehidupan seksual dan kesehatan reproduksi [8].

Peran sebagai motivator dapat dinyatakan melalui dukungan suami terhadap istri yang menggunakan alat kontrasepsi. Bentuk dukungan tersebut dapat berupa dukungan informasi, dukungan emosional, dukungan penghargaan dan dukungan instrumental. Pada dukungan informasi dapat dilakukan dalam bentuk pemberian informasi dengan membantu istri untuk menemukan alternatif yang tepat bagi penyelesaian masalah. Informasi dibutuhkan oleh ibu pengguna alat kontrasepsi mengingat apa yang sedang mereka jalani adalah hal yang baru dalam hidupnya. Dukungan informasi dapat berupa saran, nasehat dan petunjuk dari suami. Suami dapat memberikan bahan bacaan seperti buku, majalah/tabloid tentang kontrasepsi [6]. Penelitian ini ditunjukkan bahwa pada point suami mencari informasi mengenai penggunaan alat kontrasepsi, jumlah paling tinggi ibu menyatakan pada kriteria "sering".

Dukungan emosional yaitu sejauh mana individu merasa suami memberi perhatian, mendorong, serta membantu memecahkan masalah yang dihadapi individu [9]. Dukungan yang dapat diberikan suami antara lain memilih kontrasepsi yang cocok, yaitu kontrasepsi yang sesuai dengan keinginan dan kondisi istrinya, membantu pasangan dalam menggunakan kontrasepsi dengan benar seperti mengingat istri untuk kontrol, membantu mencari pertolongan bila terjadi efek samping maupun komplikasi, mengantarkan jika akan kontrol atau melakukan rujukan. Pada penelitian ini ditunjukkan bahwa pada point tersebut jumlah paling tinggi ibu menyatakan pada kriteria "sering" namun masih terdapat beberapa ibu yang menyatakan hal tersebut masih jarang dilakukan suami atau termasuk pada kriteria "kadang-kadang".

Hubungan peran suami terhadap pemilihan jenis alat kontrasepsi $\mathrm{KB}$ di Kelurahan Kebonsari Kabupaten Jember di analisis dengan uji statistik chi square didapatkan $p$ value sebesar 0,016. Pengambilan keputusan dilakukan dengan melihat derajat kemaknaan $(\alpha=0,05)$. Nilai $p$ value yang didapat dari hasil uji statistik adalah $\leq$ 0,05 maka Ha gagal ditolak, artinya terdapat hubungan antara peran suami dengan pemilihan jenis alat kontrasepsi KB pada ibu di Kelurahan Kebonsari Kabupaten Jember dan peran suami yang dilakukan memiliki kemungkinan / resiko sebesar 0,241 untuk memilih jenis alat kontrasepsi Hormonal pada ibu.

Penelitian ini menunjukkan bahwa peran suami mempengaruhi pemilihan jenis alat kontrasepsi yang digunakan ibu. Pekerjaan suami dengan presentase paling tinggi adalah sebagai PNS, dalam hal ini tunjangan yang diterima hanya untuk anak pertama dan anak kedua, hal ini mempengaruhi dalam peran suami untuk membatasi jumlah kelahiran yaitu sebatas 2 anak dengan memilih salah satu jenis alat kontrasepsi Hormonal maupun non 
Hormonal, hal ini bertujuan untuk kesejahteraan ekonomi keluarga. Data penelitian ini juga menunjukkan bahwa mayoritas ibu mempunyai jumlah anak $\leq 2$. Rata -rata umur ibu yaitu 35 tahun, umur tersebut merupakan umur yang rentan mengalami resiko kehamilan oleh karena itu peran suami sangatlah penting terutama dalam hal pemilihan jenis alat kontrasepsi. Kategori peran dilakukan yang memilih kontrasepsi non hormonal yaitu sebanyak $18 \mathrm{ibu}$, yang berbeda jauh dari kategori peran suami tidak dilakukan yang memilih non hormonal yaitu hanya 5 ibu. Peneliti berasumsi bahwa pada kategori peran suami dilakukan yang memilih kontrasepsi non hormonal dikarenakan rata-rata umur ibu adalah 35 tahun, yaitu merupakan umur dengan kehamilan beresiko, Selain itu pada ibu yang menggunakan kontrasepsi Non hormonal secara garis besar sudah memiliki 2 anak atau lebih. Pada dasarnya fungsi kontrasepsi non hormonal lebih fokus pada jangka panjang atau menghentikan kehamilan, sehingga suami kemungkinan lebih menyarankan ibu untuk memilih kontrasepsi non hormonal [10].

Pemilihan jenis kontrasepsi hormonal pada kategori peran dilakukan menunjukan tidak adanya selisih yang cukup jauh dengan kategori peran tidak dilakukan. Fungsi dari kontrasepsi hormonal adalah untuk menjarangkan atau menunda kehamilan, selain itu secara garis besar pengguna kontrasepsi hormonal adalah ibu dengan usia muda. Pada hasil wawancara saat pengisian kuesioner, terdapat beberapa ibu dengan usia kehamilan beresiko tetap menggunakan kontrasepsi hormonal, hal ini dikarenakan adanya keluhan beberapa suami tentang alat kontrasepsi Non Hormonal seperti ketidaknyamanan saat berhubungan seks karena penggunaan kontrasepsi Non Hormonal yaitu IUD, tetapi ada juga suami yang tidak mempermasalahkan hal tersebut [11]. Ibu masih merasa takut dan kurang yakin apabila menggunakan jenis kontrasepsi Non Hormonal, dikarenakan prosesnya yang menggunakan prosedur bedah dan terkesan lebih rumit daripada penggunaan kontrasepsi jenis Hormonal meskipun jenis
Non Hormonal mempunyai tingkat efektivitas yang lebih tinggi daripada jenis Hormonal [12]. Dalam hal ini kemungkinan suami menyarankan memilih kontrasepsi hormonal dikarenakan istri masih merasa kurang yakin dan takut dengan metode kontrasepsi non hormonal dan terdapat faktor lain, seperti kenyamanan suami dalam berhubungan seks, sehingga peran suami lebih fokus pada kebutuhan keluarga serta kondisi istri.

Penelitian sebelumnya menyatakan bahwa kenyamanan suami saat berhubungan seks juga mempengaruhi terhadap pemilihan jenis kontrasepsi, suami cenderung menyarankan istrinya menggunakan jenis kontrasepsi yang dirasa nyaman bagi suami maupun istri dan tidak menimbulkan efek yang negatif pada istri maupun suami [4].

Penelitian ini menunjukkan bahwa dalam pemilihan jenis kontrasepsi hormonal peran suami banyak yang tidak dilakukan 40.4 \%. Hal ini di karenakan terdapat nilai yang rendah pada beberapa point seperti mengantar ibu kontrol kontrasepsi, aktif dalam konsultasi kontrasepsi dan mengingatkan penggunaan / kontrol rutin alat kontrasepsi hormonal serta mendengarkan keluhan istri tentang $\mathrm{KB}$, sehingga hal tersebut sedikit banyak mempengaruhi pada nilai peran suami terhadap pemilihan kontrasepsi yang digunakan ibu. Bentuk perhatian suami akan memberikan hubungan yang hangat, sangat peduli, kedekatan dan saling mendengarkan. Semakin tinggi perhatian suami, semakin rendah tingkat kecemasan istri begitu juga sebaliknya, semakin rendah dukungan emosional suami semakin tinggi tingkat kecemasan istri, Apabila hal tersebut tidak dilakukan menyebabkan ibu merasa kurang diperhatikan secara emosional oleh suami sehingga dapat menggurangi semangat ibu untuk melakukan kunjungan ulang $\mathrm{KB}$ sesuai jadwal [13]. Pada kategori pemilihan kontrasepsi Non Hormonal peran suami yang tidak dilakukan hanya 5.3\%, yang terpaut cukup jauh dari peran yang dilakukan $19.1 \%$, hal ini menunjukkan bahwa jenis kontrasepsi non hormonal 
memerlukan pemikiran yang matang antara pasangan suami istri, dikarenakan bersifat jangka panjang dan permanen [1].

\section{KESIMPULAN DAN SARAN Kesimpulan}

Hasil penelitian menunjukkan Pada kategori peran suami dalam pemilihan jenis kontrasepsi KB pada ibu, lebih dari setengah ibu menyatakan bahwa peran suami dilakukan dengan presentase $54.3 \%$. Pada jenis alat kontrasepsi yang digunakan ibu, menunjukkan bahwa mayoritas ibu menggunakan kategori alat kontrasepsi Hormonal dengan presentase $75.5 \%$.

Terdapat hubungan peran suami terhadap pemilihan jenis kontrasepsi KB di Kelurahan Kebonsari Kabupaten Jember, dengan nilai $\mathrm{P}=0,016$ dengan $\alpha=0,05$ dan peran suami yang dilakukan memiliki kemungkinan / resiko sebesar 0,241 untuk memilih jenis alat kontrasepsi Hormonal pada ibu.

\section{Saran}

Saran bagi tenaga kesehatan khususnya perawat baik di puskesmas maupun di Rumah Sakit atau Klinik untuk meningkatkan program penyuluhan tentang alat kontrasepsi dan konseling kontrasepsi KB pada keluarga terutama pada suami agar dapat melakukan pengawasan alat kontrasepsi pada istri. Saran bagi BKKBN Kabupaten Jember diharapkan dapat lebih bekerja sama dengan pihak Puskesmas, Rumah Sakit serta BPS untuk mengedepankan pelayanan informasi maupun konseling tentang kontrasepsi. Bagi masyarakat dan keluarga diharapkan lebih meningkatkan peran suami dalam pemilihan maupun penggunaan alat kontrasepsi dan menghapuskan anggapan bahwa alat kontrasepsi hanya masalah istri. Peran tokoh masyarakat diharapkan lebih optimal dalam meningkatkan peran suami dalam pemilihan jenis alat kontraesepsi KB pada ibu.

\section{DAFTAR PUSTAKA}

[1]BKKBN. Buku pedoman pelayanan keluarga berencana edisi ketiga. Jakarta; 2009.
[2]BKKBN. Laporan DALAP pelayanan kontrasepsi.[internet] [place unknown]. 2014 [cited 2014 februari 20]. Available from: http://aplikasi.bkkbn.go.id/sr

[3]Hanafi H. Keluarga berencana dan kontrasepsi. Jakarta: Pustaka Sinar Harapan; 2002.

[4]Rafidah I. Pengaruh dukungan suami terhadap kepatuhan akseptor melakukan KB suntik. Surabaya: Departemen Biostatistika dan Kependudukan FKM UNAIR; 2012.

[5]Friedman MM. Keperawatan keluarga: teori \& praktek. Jakarta: EGC; 2010.

[6]Hartanto H. Keluarga berencana dan kontrasepsi. Jakarta: Pustaka Sinar Harapan; 2004.

[7]Pendit BU. Ragam metode kontrasepsi. EGC: Jakarta; 2006.

[8]Bobak L. Buku ajar keperawatan maternitas. Jakarta: EGC; 2004.

[9]Musbikin. Panduan kontrasepsi. Jogjakarta: Mitra Pustaka; 2008.

[10]Lestari N. Pelayanan kontrasepsi. BKKBN Provinsi Jawa Timur; 2009.

[11]Adyani RA. Faktor-faktor yang berhubungan dengan pemilihan kontrasepsi Non IUD pada akseptor KB wanita Usia 20-39 Tahun. Semarang: UNDIP; 2009.

[12]Speroff L. Pedoman klinis kontrasepsi edisi 2. Jakarta: EGC; 2003.

[13]Glasier A. Keluarga berencana dan kesehatan reproduksi edisi 4. Jakarta: EGC; 2002.

[14]Saifudin Abdul B. 2006. Buku Panduan Praktis Pelayanan kontrasepsi. Edisi Kedua. Jakarta : Yayasan Bina Sarwono Prawiroharjo.

[15]Speroff, Leon. 2003. Pedoman Klinis Kontrasepsi edisi 2. Jakarta : EGC

[16] Siswosudarmo, dkk. 2001. Teknologi Kontrasepsi. Jakarta : UGM

[17] Witjaksono, Julianto. 2012. Rencana Aksi Keluarga Berencana dan Kesehatan Reproduksi. DEPUTI BIDANG KB dan KR 
JURNAL ILMIAH KESEHATAN MEDIAHUSADA | VOLUME 05/NOMOR 01/MARET 2016 